\title{
Cenzura wojskowa w komunistycznej Polsce i jej wpływ na powstanie i funkcjonowanie GUKPPiW
}

Streszczenie: Najstarszą i najdłużej działająca instytucją kontrolującą media w komunistycznej Polsce była cenzura wojskowa powstała pod koniec II wojny światowej. Służba ta zorganizowana była na wzór cenzury sowieckiej i pod kierownictwem oficerów sowieckiego wywiadu wojskowego GRU. Cenzorzy wojskowy kontrolowali oprócz wydawnictw wojskowych również media cywilne. Specjalny Wydział Wojskowy funkcjonujący w strukturach cywilnej cenzury - Główny Urząd Kontroli Prasy, Publikacji i Widowisk, odpowiadał za ochronę tajemnicy wojskowej i szkolenie cenzorów cywilnych w zakresie obronności. Oficerowie cenzury wojskowej pod pozorem ochrony tajemnic wojskowych nie dopuszczali do druku informacji o wykroczeniach i przestępstwach dokonywanych przez przedstawicieli wojska, w ten sposób znacząco ograniczali cywilną kontrolę nad siłami zbrojnymi PRL.

Słowa-klucze: Wojsko Polskie, sowiecki wywiad wojskowy, cenzura wojskowa, kontrola mediów cywilnych.

\footnotetext{
Mariusz Patelski - dr hab., adiunkt w Instytucie Historii Uniwersytetu Opolskiego, autor i redaktor prac z zakresu historii politycznej i wojskowej XIX i XX w., w tym: Generat broni Tadeusz Jordan Rozwadowski - żotnierz i dyplomata (Warszawa 2003); Niezależne Zrzeszenie Studentów w Opolu 1980-1990. Zarys działalności na tle lokalnego środowiska akademickiego (Opole 2010), T. Jordan Rozwadowski, Wspomnienia Wielkiej Wojny (Warszawa 2015), ,, Czujni strażicy Demokracji” Ludowej. Urząd cenzury w województwie opolskim 1950-1990 (Opole 2019).
} 


\section{The Military Censorship in Communist Poland and its influence on the inception and functioning of GUKPPiW (Główny Urząd Kontroli Prasy, Publikacji i Widowisk - The Main Office of Control of the Press)}

Summary: The Military Censorship, developed at the end of World War II, was the oldest and longest working institution controlling the media in Communist Poland. This service was based on the Soviet Censorship and was under the leadership of The Soviet Military Intelligence officers. Apart from military publishing house, military censors controlled the civil media. A Special Military Department functioning in civil censorship organizations - The Main Office of Control of the Press, Publications and Shows, was responsible for protecting of military secrets and civil censors' training. Military Censorship officers, under the guise of military secrets protection, did not allow printing any information concerning violations and crimes commited by military representatives, which significantly reduced civil control over the military forces in the Polish People's Republic.

Key words: The Polish People's Army, Soviet Military Intelligence, Military Censorship, the civil media control.

Jednym z najistotniejszych filarów wspierających władze komunistyczne w Polsce była instytucja cenzury. W latach 1944-1945 wraz z organizowaniem się i konsolidowaniem nowych komunistycznych władz aparat cenzury był też stopniowo rozbudowywany. Pierwotnie funkcje cenzorskie pełnili pracownicy Ministerstwa Informacji i Propagandy, w tym stojący na czele Wydziału Informacyjno-Prasowego - Jerzy Borejsza, który przygotował projekt dekretu prasowego, zakładający dość liberalne zasady działania cenzury. Projekt Borejszy spotkał się jednak z krytyką członka Biura Politycznego KC PPR i podsekretarza stanu w Prezydium Rady Ministrów - Jakuba Bermana, który był zwolennikiem sowieckich rozwiązań związanych z funkcjonowaniem propagandy i działaniem cenzury ${ }^{1}$. Na zaproszenie Bermana, w listopadzie 1944

1 Z. Romek, Cenzura a nauka historyczna w Polsce 1944-1970, Warszawa 2010, s. 33-35. 
roku, przybyli do Lublina funkcjonariusze sowieckiego Gławlitu (Gławnoje Uprawlienie po Diełam Litieratury i Isskustwa) - Piotr Gołdin i Kazimierz Jarmuž, którzy mieli nadzorować tworzenie struktur polskiej cenzury. Pod ich przewodnictwem powstało, w strukturach Ministerstwa Bezpieczeństwa Państwowego (MBP), Centralne Biuro Kontroli Prasy (CBKP), które przejęło zadania cenzorskie od urzędników Ministerstwa Informacji i Propagandy. Oficjalnym dokumentem powołującym nową instytucję był rozkaz nr 2 z 19 stycznia 1945 roku Ministra Bezpieczeństwa Publicznego Stanisława Radkiewicza o zorganizowaniu przy Ministerstwie Bezpieczeństwa Publicznego Centralnego Biura Kontroli Prasy, na czele którego miał stanąć Leon Rzendowski². 15 listopada 1945 roku uchwałą Rady Ministrów nastąpiła reorganizacja cenzury i Biuro, już pod zmienioną nazwą - jako Główny Urząd Kontroli Prasy Publikacji i Widowisk (GUKPPiW), przeszło z resortu bezpieczeństwa publicznego pod zwierzchnictwo Prezydium Rady Ministrów. Uchwała stanowiła ogólnie, że GUKPPiW „i podległe mu organy właściwe są we wszystkich sprawach dotyczących kontroli publikacji i widowisk, dla których na podstawie przepisów dotychczas obowiązujących właściwe były inne organy administracji państwowej”3.

Istnienie tej instytucji zostało oficjalnie usankcjonowane dekretem z 5 lipca 1946 roku o utworzeniu Głównego Urzędu Kontroli Prasy, Publikacji i Widowisk. W dokumencie tym określono także kompetencje Urzędu. Jego zadania były następujące: „nadzór nad prasą, publikacjami i widowiskami” oraz „kontrola rozpowszechniania wszelkiego rodzaju utworów za pomocą druku, obrazu i żywego słowa w celu zapobieżenia: a) godzenia w ustrój państwa, b) ujawniania tajemnic państwowych, c) naruszania międzynarodowych stosunków Państwa Polskiego, d) naruszania prawa lub dobrych obyczajów, e) wprowadzania w błąd opinii publicznej przez podawanie wiadomości niezgodnych z rzeczywistością". Prezes Rady Ministrów miał ustalić organizację Głównego Urzędu i urzędów terenowych ${ }^{4}$.

2 Glówny Urząd Kontroli Prasy 1945-1949, oprac. D. Nałęcz, Warszawa 1994, s. 15; M. Oczkowski, Zmiany $w$ organizacji i zakresie działania władz administracji ogólnej, „Gazeta Administracyjna" 1945, nr 1-3, s. 27.

3 Cyt. za: M. Ciećwierz, Polityka prasowa 1944-1948, Warszawa 1989, s. 183.

4 „Dziennik Ustaw” (dalej: Dz.U.) 1946, nr 34, poz. 210. 
GUKPPiW nie był jedyną instytucja powołaną przez władze komunistyczne do działalności cenzorskiej. 1 września 1944 roku, na podstawie rozkazu kierownika Resortu Bezpieczeństwa Publicznego - Stanisława Radkiewicza, utworzony został Wydział Cenzury, który miał prowadzić kontrolę (perlustrację) cywilnych przesyłek pocztowych ${ }^{5}$. Działalność Wydziału Cenzury została usankcjonowana dopiero 28 grudnia 1944 roku dekretem o wprowadzeniu wojennej cenzury korespondencji6. Odpowiedzialny za perlustrację korespondencji Wydział Cenzury, później Główny Urząd Cenzury (nazwa zmieniała się w zależności od okresu), funkcjonował w strukturach MBP, a następnie MSW aż do 30 maja 1989 roku? $^{7}$.

Najstarszą i najdłużej działającą instytucją odpowiedzialną za kontrolę informacji była jednak, sformowana wedle wzorów sowieckich, z udziałem i pod kontrolą oficerów sowieckiego wywiadu wojskowego GRU (Glawnoje Razwiedywatielnoje Uprawlenije), cenzura wojskowa. Jej początki sięgają połowy 1943 roku i organizowania w Związku Sowieckim, pod ideowym kierownictwem polskich komunistów i nadzorem sowieckich dowódców wojskowych, oddziałów 1. Dywizji Piechoty im. Tadeusza Kościuszki ${ }^{8}$. Proces formowania służb cenzorskich w szeregach wojska towarzyszył zapewne powstaniu pierwszych gazet frontowych: „Żołnierza Wolności” i „Zwyciężymy"9. Cenzorzy wojskowi od początku realizowali też dwa zadania: kontrolowali korespondencję żołnierską oraz wydawnictwa wojskowe ${ }^{10}$.

5 P. Sowiński, Kontrola pierwszomajowa, „Karta” 1998, nr 25, s. 4.

6 Dz.U. 1944, nr 17, poz. 93.

7 G. Majchrzak, ,,Wojenna” cenzura, „Biuletyn Instytutu Pamięci Narodowej” 2004, nr 2, s. $50-51$.

8 S. Cenckiewicz, Dlugie ramie Moskwy. Wywiad wojskowy Polski Ludowej 1943-1991, Warszawa 2009, s. 45; Wojsko Polskie w II wojnie światowej, pod red. E. Kospath-Pawłowskiego, Warszawa 1994, s. 169.

9 P. Pakier, Prasa frontowa Ludowego Wojska Polskiego w latach 1943-1945, „Rocznik Historii Czasopiśmiennictwa Polskiego" 1967, z. 1, s. 128.

10 J. Kochanowski, Lubelskie czarne gabinety. Sprawozdania cenzury wojennej z 1944 roku. „Polska 1944/45-1989. Studia i Materiały” 1999, t. IV, s. 325-326. 


\section{Formowanie komórek cenzury wojskowej w Wojsku Polskim (1944-1945)}

Szybki rozwój cenzury wojskowej w końcu II wojny światowej wiązał się z ofensywą wojsk sowieckich przeciw Niemcom, wkroczeniem Armii Czerwonej na ziemie polskie i formowaniem nowych wielkich jednostek Wojska Polskiego na szczeblu operacyjnym. 24 czerwca 1944 roku dowódca 1 Armii WP gen. Zygmunt Berling wydał rozkaz o organizacji cenzury prasy. Zgodnie z zapisami tego rozkazu, cenzorzy wojskowi poszczególnych dywizji wyznaczani byli spośród oficerów sztabu dywizji i w porozumieniu z cenzorem wojennym armii. Od cenzora wymagano dobrej znajomości języka polskiego i „zrozumienia tajemnicy państwowej”. Cenzorzy podlegali dowódcom dywizji i przed nimi odpowiadali za wykonywane obowiązki, natomiast w sprawach fachowych podlegali cenzorowi wojennemu 1. Armii. Do obowiązków cenzora wojennego dywizji należała: kontrola wychodzących w danej formacji gazet, cenzura wszystkich druków, a także repertuaru zespołów artystycznych, wystaw i gazetek ściennych. Oficer odpowiedzialny za cenzurę zobowiązany był przesyłać cenzorowi wojennemu armii sprawozdania ze swej pracy oraz wszystkie wydawnictwa wydawane w danej dywizji. Cenzorom nie wolno było należeć do redakcji gazet podlegających ich kontroli, a ich korespondencja była tajna. Cenzor i redaktor odpowiadali także za ochronę tajemnicy wojskowej we wszystkich drukach wykonywanych w drukarni dywizyjnej. Bez zgody cenzorów nie można było wypuszczać (rozpowszechniać) gazet ${ }^{11}$. Funkcję cenzora 1 . Armii pełnił w tym czasie mjr Roman Jarzębkiewicz (Jarząbkiewicz) ${ }^{12}$. Wkrótce podobne komórki cenzorskie powołano także w nowo powstałej 2. Armii WP, a zakres ich obowiązków był zapewne podobny ${ }^{13}$.

11 Rozkaz ogólny nr 0114/KG dowódcy 1 armii o organizacji cenzury prasy, Chopniów 24 VI 1944, [w:] Organizacja i działania bojowe Ludowego Wojska Polskiego w latach 1943-1945, t. 1, oprac. L. Ponahajba, Warszawa 1958, s. 89-90; I. Błagowieszczański, Dzieje 1 Armii Polskiej w ZSRR. Maj-lipiec 1944 r., Warszawa 1972, s. 64.

12 Archiwum Instytutu Pamięci Narodowej w Warszawie (dalej: IPN W), Zarząd II Sztabu Generalnego Wojska Polskiego w Warszawie (dalej: Zarząd II Sztabu Gen. WP), sygn. BU 2602/53, Mjr Jąrząbkiewicz, Miesięczne sprawozdanie z czynności cenzora wojskowego przy sztabie 1. Armii WP, za czas od 1 IX 1944 r. do 20 IX 1944 r., M.p. 1 X 1944 r., k. $42-43$.

13 T. Stępniowski, Z dziejów 2 Armii Wojska Polskiego. Zarys formowania i organizacji, Warszawa 1962, s. 143. 
Kolejny etap w formowaniu wojskowych służb cenzorskich nastąpił z chwilą powołania, 20 sierpnia 1944 roku rozkazem $\mathrm{nr} 8$ Naczelnego Dowódcy WP - Michała Roli-Żymierskiego, Sztabu Głównego WP. Zgodnie z tą dyrektywą, do 15 września 1944 roku miało powstać w Lublinie kierownictwo i sekretariat Sztabu Głównego, w którym znalazł się także etat „głównego cenzora wojskowego". Funkcję tę pełnił początkowo, oddelegowany do WP, oficer sowieckiego GRU - mjr/ppłk Anatol (Anatolij) Bogatyrow ${ }^{14}$, a następnie mjr/ppłk Roman Jarzębkiewicz ${ }^{15}$. Mjr Bogatyrow, jak wynika z zachowanych dokumentów, przystąpił do swych zadań już 16 września 1944 roku. Tego dnia do redakcji wojskowej 1. Armii WP wysłano: „Instrukcję o cenzurze wojskowej w Wojsku Polskim” na czas wojny oraz „Instrukcję dla drukarni wojskowych Wojska Polskiego"16. Główny cenzor wojskowy nie ograniczał swych zadań wyłącznie do wydawnictw wojskowych, w tym samym czasie bowiem instrukcja pod tytułem „Wykaz wiadomości, których w prasie publikować nie wolno” została rozesłana także do redakcji: „Rzeczpospolitej”, Polskiego Radia w Lublinie oraz „Gazety Lubelskiej”17. Wkrótce potem mjr Bogatyrow przeprowadził, wspólnie „z przedstawicielem ZSSR” przy PKWN - ppłk. Filinem, kontrolę wydawnictw 1. Armii WP, która miała wykazać szereg przypadków łamania tajemnicy wojskowej, o czym poinformowano zarówno polskie dowództwo, jak i przedstawicieli wojsk sowieckich ${ }^{18}$.

Obok komórki służącej kontroli mediów władze wojskowe przystąpiły także do tworzenia służb odpowiedzialnych za perlustrację żołnierskiej kore-

14 S. Cenckiewicz, dz. cyt., s. 94.

15 B. Dolata, Krótki zarys rozwoju władz naczelnych i instytucji Ludowego Wojska Polskiego w latach 1944-1945, [w:] Zzagadnień rozwoju Ludowego Wojska Polskiego, pod red. J. Margulesa, Warszawa 1964, s. 47-48.

16 IPN W, Zarząd II Sztabu Gen. WP, sygn. BU 2602/50, Mjr A. Bogatyrow, Meldunek do szefa Sztabu Głównego WP gen. S. Zarako-Zarakowskiego, 16 X 1944 r., k. 114.

17 IPN W, Zarząd II Sztabu Gen. WP, sygn. BU 2602/50; Mjr A. Bogatyrow, Pismo do Redakcji „Gazety Lubelskiej”, M.p. 16 IX 1944 r., k. 118.

18 W wyniku kontroli cenzorzy stwierdzili przypadki łamania tajemnicy wojskowej, między innymi ujawnianie w artykułach publikowanych w gazecie 1. Amii WP pt. „Zwyciężymy”, nazwisk dowódców pułków i dywizji. Nagannym było także, zdaniem mjr. Bogatyrowa, rozdawanie egzemplarzy tej gazety wśród ludności cywilnej między innymi na Pradze oraz rozklejanie poszczególnych egzemplarzy na ścianach i płotach, co mogło pomóc nieprzyjacielowi w lokalizacji dowództwa 1. Armii. IPN W, Zarząd II Sztabu Gen. WP, sygn. BU 2602/50, Mjr A. Bogatyrow, Meldunek do szefa Sztabu Głównego WP gen. S. Zarako-Zarakowskiego, 16 X 1944 r., k. 95. 
spondencji. Od 8 października przy Naczelnym Dowództwie WP oraz w dowództwie 1. 2. oraz 3. Armii rozpoczęto też tworzenie wojskowych komórek cenzury, których działalność koncentrowała się na kontroli korespondencji poczty polowej ${ }^{19}$. Wkrótce zorganizowano: 40, 190, 191 i 192 oddziały cenzury wojskowej, które podlegały Wydziałowi Cenzury Wojennej ${ }^{20}$. Do służby w tych oddziałach powołano, w październiku 1944 roku, między innymi 67 ochotniczek z 1. Samodzielnego Batalionu Kobiecego im. Emilii Plater ${ }^{21}$.

Istotne decyzje, rozszerzające kompetencje cenzorów wojskowych, zapadły w pierwszej połowie września 1944 roku. W Sztabie Głównym opracowano wówczas „Instrukcję o organizacji i zakresie działania wojskowych organów cenzury w Wojsku Polskim”. Wedle zapisów jakie znalazły się w tym dokumencie, cenzorzy wojskowi mieli kontrolować wszystkie wydawnictwa drukowane, w tym także prasę cywilną, programy radiowe, filmy, wystawy oraz wszelkiego typu druki zwarte i ulotne ${ }^{22}$. Jak stąd wynika, dowództwo wojskowe, podobnie jak przedstawiciele resortu bezpieczeństwa, nie ufało działaniom urzędników Resortu Informacji i Propagandy w zakresie kontroli mediów, dlatego zamierzało przekazać obowiązek kontroli prasy cywilnej cenzorom wojskowym.

Wstępne prace nad organizacją aparatu cenzury wojskowej trwały do 30 listopada 1944 roku. Tego dnia został wydany przez Naczelnego Dowódcę WP rozkaz organizacyjny nr 78/org., który polecał cenzorowi Sztabu Głównego utworzenie Oddziału Cenzury Wojskowej (OCW) przy Sztabie Głównym Naczelnego Dowództwa WP. Oddział miał się składać, wedle etatu nr D1/14, $\mathrm{z}$ kierownictwa, to jest $\mathrm{z}$ szefa oddziału i jednocześnie cenzora kolejnej kontroli periodycznych wydawnictw wojskowych, jego zastępcy i jednocześnie cenzora wydawnictw periodycznych Sztabu Głównego WP oraz adiutanta. Ponadto do składu OCW mieli należeć: kancelista, maszynistka oraz 15 cenzorów. Odział, ze względu na konieczność poruszania się między różnym ośrodkami,

19 B. Dolata, Zarys organizacji i działalności Sztabu Głównego Wojska Polskiego w latach 1944-1945, „Wojskowy Przegląd Historyczny” 1968, nr 3, s. 317.

20 IPN W, Resort Bezpieczeństwa Publicznego w Lublinie, sygn. BU 1576/31, Mjr. M. Rossner, Sprawozdanie Oddziału Cenzury Wojskowej za okres do 5 XI 1944 r., 4 XI 1944, k. 1-2.

21 S. Drzewiecka, 1 Samodzielny Batalion Kobiecy im. Emilii Plater, „Wojskowy Przegląd Historyczny" 1958, nr 3, s. 198; Tejże, Szłyśmy znad Oki, Warszawa 1985, s. 143, 265, 279.

22 B. Dolata, dz. cyt., s. 317-318. 
w których wychodziła lokalna prasa, miał być ponadto wyposażony w samochód marki Willis ${ }^{23}$.

W listopadzie szefem OCW mianowano sowieckiego oficera GRU oddelegowanego do Wojska Polskiego - ppłk. Sergiusza (Sergieja) Orżewskiego. Orżewski służył w OCW, jednak bardzo krótko, bo już 1 grudnia 1944 roku został przeniesiony na stanowisko zastępcy szefa Oddziału RozpoznawczoWywiadowczego do spraw zwiadu i informacji Sztabu Głównego WP24. Jego następcą został w grudnia 1945 roku doświadczony cenzor - ppłk Anatol Bogatyrow $^{25}$, funkcję zastępcy szefa OCW powierzono, natomiast, ppłk. Romanowi Jarzębkiewiczowi ${ }^{26}$. W składzie OCW znaleźli się ponadto: por. Lucjan Haine (Heine) - cenzor gazety „Robotnik”, kpt. Arkadiusz Proniński - cenzor „Rzeczpospolitej”, por. Aleksander Ostrowski - cenzor „Tygodnika Lubelskiego”, por. Bolesław Kunach - cenzor w Rzeszowie i Tarnowie („Gazeta Rzeszowska"), por. Euzebiusz Zwoliński - cenzor w Chełmie i Siedlcach („Ziemia Chełmska”), por. Stefan Żółtowski - cenzor w Przemyślu, kpt. Jerzy Kuczewski - cenzor w Sandomierzu („Wolna Polska”), por. Feliks Jurczyński - cenzor na Pradze (,Życie Warszawy”) oraz kpt. Stanisław Okupniak - cenzor Polpressu, a ponadto sierż. Feliks Jurczyński - adiutant oraz Zofia Maj - kancelistka ${ }^{27}$.

18 grudnia 1944 roku ppłk Bogatyrow, w meldunku do szefa Sztabu Głównego WP, poinformował o zakończeniu prac nad organizacją OCW. Przy okazji wyraził następującą opinię o służących w Oddziale oficerach: „Z powodu braku personelu z wykształceniem i praktyką w sprawie cenzury wojskowej, oddział sformuowany (sic!) został z oficerów, nie mających dotychczas praktyki w tej dziedzinie. Większość natomiast oficerów oddziału, posiada wyższe

23 Zgodnie z etatem nr D1/14, Oddział Cenzury Wojskowej był wyposażony także w 15 pistoletów. IPN W, Zarząd II Sztabu Gen. WP, sygn. BU 2602/54, Etat nr D1/14, k. 64, 67.

24 B. Dolata, dz. cyt., s. 318; S. Cenckiewicz, dz. cyt., s. 98. A. Nogaj, Powstanie i organizacja Oddziału Wywiadowczego Sztabu Głównego Wojska Polskiego w latach 1944-1945, [w:] Studia nad wywiadem i kontrwywiadem Polski $w$ XX wieku, t. 1, pod red. W. Skóry i P. Skubisza, Szczecin 2016, s. 574.

25 IPN W, Zarząd II Sztabu Gen. WP, sygn. BU 2602/50, A. Bogatyrow, Meldunek do Szefa Sztabu Głównego WP gen. S. Zarako-Zarakowskiego, 18 XII 1944 r., k. 98.

26 B. Dolata, dz. cyt., s. 318.

27 IPN W, Zarząd II Sztabu Gen. WP, sygn. BU 2602/54, Wyciąg z rozkazu personalnego nr 146, M.p., 29 XII 1944 r., k . 61-62; B. Dolata, dz. cyt., s. 341. 
wykształcenie, doświadczenie życiowe oraz krótszą lub dłuższą służbę zawodową" 28 . Z powyższych względów oficerowie służący w OCW mieli być poddani intensywnemu szkoleniu cenzorskiemu. Szef cenzorów, obok niedostatecznego wyszkolenia swych podwładnych, do największych mankamentów utrudniających bieżącą pracę cenzorów zaliczył brak dekretu państwowego, który sankcjonowałby działalność kontrolną w redakcjach prasowych. Z powodu nieistnienia odpowiednich przepisów, część redaktorów zwłaszcza gazet centralnych odmawiała współpracy z oficerami z OCW ${ }^{29}$.

Problem ten z całą ostrością wystąpił podczas kontroli prasy jaką oficerowie OCW przeprowadzili pomiędzy 29 grudnia 1944 roku i 3 stycznia 1945 roku. W meldunku z tych działań, skierowanym przez ppłk. Bogatyrowa do szefa Sztabu Głównego WP gen. Władysława Korczyca, szef cenzury napisał między innymi: „Najtrudniejszą jest sprawa gazet centralnych, które służą wzorem całej prasy prowincjonalnej. Redaktor gazet »Rzeczpospolita« i »Robotnik « mjr [Jerzy] Borejsza kategorycznie odmówił wprowadzenia cenzury wojskowej do wyżej wymienionych gazet, tłumacząc odmowę tem, że gazety te są gazetami państwowemi, niemającemi nic wspólnego z wojskiem, a tem samem nie podlegają cenzurze wojskowej. Oświadcza on, że cenzora wojskowego do gazet »Rzeczpospolita« $\mathrm{i} »$ Robotnik« dopuści do pracy wtedy, gdy będzie państwowy dekret, wprowadzający cenzurę wojskową do prasy cywilnej. Sprzeciw swój tłumaczy on tem, że cenzor wojskowy będzie utrudniać techniczną pracę druku gazety"30. O wszelkich przypadkach ujawnienia tajemnicy wojskowej w prasie cywilnej, w tym także w „Rzeczpospolitej” szef OCW informował także gen. Borysa Šatilova - zastępca gen. Nikołaja Bułganina, sowieckiego attaché wojskowego ${ }^{31}$.

28 IPN W, Zarząd II Sztabu Gen. WP, sygn. BU 2602/50, A. Bogatyrow, Meldunek do Szefa Sztabu Głównego WP gen. S. Zarako Zarakowskiego, 18 XII 1944 r., k. 98.

29 W tym czasie siedziba OCW znajdował się w Lublinie przy ul. Szopena 7, a następnie, w lutym 1945 r., została przeniesiona wraz z innymi instytucjami Sztabu Gen. WP do Włoch pod Warszawą. Tamże, A. Bogatyrow, Meldunek do Szefa Sztabu Głównego WP gen. S. Zarako-Zarakowskiego, 18 XII 1944 r., k. 98; IPN W, Zarząd II Sztabu Gen. WP, sygn. IPN BU 2602/49, Kpt. J. Kuczewski, Raport do Szefa OCW Sztabu Gł. WP, [po 9 II 1945 r.], k. 12.

30 IPN W, Zarząd II Sztabu Gen. WP, sygn. BU 2602/50, Mjr A. Bogatyrow, Meldunek do szefa Sztabu Gen. gen. W. Korczyca, 10 I 1945 r., k. 77.

31 Z. Romek, dz. cyt., s. 34; IPN sygn. Zarząd II Sztabu Gen. WP, BU 2602/50, Mjr A. Bogatyrow, Notatka do tow. Šatilova, 10 I 1945 r., k. 75-76. 
Najprawdopodobniej w związku z tymi wydarzeniami w OCW powstał projekt rozporządzenia Szefa Sztabu Głównego WP zezwalającego na kontrolę prasy cywilnej przez cenzurę wojskową. Rozporządzenie to miało obowiązywać do czasu uchwalenia przez rząd odpowiedniego dekretu o cenzurze. W dokumencie tym znalazł się także zapis, iż na czas wojny zostanie przydzielonych czterech wojskowych cenzorów do „Centralnego Biura Kontroli Prasy, Kina i Radia przy Ministerstwie Bezpieczeństwa Publicznego, dla usprawnienia ochrony tajemnic wojskowych"32. Nie jest jasne, czy rozporządzenie Sztabu Głównego zostało wydane, ale w rozkazie nr 2 z 19 stycznia 1945 roku Ministra Bezpieczeństwa Publicznego, powołującym Centralne Biuro Kontroli Prasy znalazł się zapisy, w myśl którego do CBKP przydzielono dwóch cenzorów z Wydziału Cenzury Wojennej MBP oraz trzech cenzorów wojskowych: por. Kuczewskiego, kpt. Okupniaka i por. Ostrowskiego z Oddziału Cenzury Wojskowej Sztabu Głównego WP ${ }^{33}$. Niewykluczone, iż w tym czasie istniał spór kompetencyjny pomiędzy przedstawicielami resortu bezpieczeństwa a przedstawicielami cenzury wojskowej dotyczący kontroli mediów cywilnych. Rozkaz Ministra Bezpieczeństwa z 19 stycznia, w którym dopuszczono udział przedstawicieli cenzury wojskowej do sprawowania nadzoru nad prasą cywilną, mógł być też wyrazem zawartego wówczas kompromisu.

W następnych tygodniach liczba oddelegowywanych do CBKP cenzorów wojskowych zwiększyła się. Niektórzy z nich, po pewnym czasie, powrócili do pracy w cenzurze wojskowej, inni pozostali w CBKP na dłużej. Niektórzy z cenzorów wojskowych wnieśli istotny wkład w formowaniu struktur terytorialnych CBKP. Kpt. Jerzy Kuczewski organizował Wojewódzkie Biuro Kontroli Prasy w Krakowie oraz kontrolował trzy miejscowe gazety, natomiast por. Euzebiusz Zwoliński współorganizował Powiatowe Biuro Kontroli Prasy w Siedlcach ${ }^{34}$.

Obok działalności kontrolnej cenzorzy z OCW odegrali istotną rolę w tworzeniu instrukcji określających zadania i obowiązki pracowników tych

32 IPN W, Zarząd II Sztabu Gen. WP, sygn. BU 2602/50, Rozporządzenie Głównego Sztabu Wojska Polskiego, Lublin 12 I 1945 r., k. 73.

33 IPN W, Ministerstwo Spraw Wewnętrznych, sygn. BU 01225/26, Ministerstwo Bezpieczeństwa Publicznego, Rozkaz nr 2, Lublin 12 I 1945 r., k. 25.

34 IPN W, Zarząd II Sztabu Gen. WP, sygn. IPN BU 2602/49, Kpt. J. Kuczewski, Raport do Szefa OCW Sztabu Gł. WP, [po 9 II 1945 r.], k. 13. 
służb. Pierwsze dokumenty, jak pośrednio wynika ze sprawozdania kpt. Pronińskiego, były tłumaczone z języka rosyjskiego. Informacja ta dotyczy, najprawdopodobniej, dołączonych do sprawozdania Pronińskiego, dokumentów: „Instrukcji dla cenzora wojskowego w czasie pokoju”, „Obowiązki cenzora wojskowego”, „Wiadomości, których w prasie drukować nie wolno” oraz „Instrukcje dla drukarni wojskowych"35.

Cenzorzy wojskowi, mimo powstania CBKP, nadal prowadzili kontrolę wtórną wychodzącej na ich terenie prasy cywilnej. W przypadkach naruszenia tajemnicy wojskowej szef OCW interweniował $\mathrm{u}$ władz zwierzchnich, domagając się surowych kar dla pracowników CBKP winnych przeoczeń cenzorskich. W lipcu 1945 roku ppłk Jarzębkiewicz zażądał, w związku z ukazaniem się w „Rzeczpospolitej” tekstu o 1. Zapasowym Pułku Piechoty, surowego ukarania dyrektora CBKP Tadeusza Zabłudowskiego. Jako powód podał ujawnienie na łamach gazety numeru pułku, nazwiska dowódcy oraz miejsca jego stacjonowania, co było sprzeczne z instrukcją o przestrzeganiu tajemnicy wojskowej. Szef OCW zarzucił też dyrektorowi Zabłudowskiemu, iż: „nie interesuje się cenzurą wojskową, ani też pouczył podwładnych co należy do tajemnic wojskowych"36. Z dostępnych materiałów nie wynika czy i jakie konsekwencje spotkały dyrektora CBKP.

OCW istniał w pierwotnym kształcie do 6 marca 1945 roku, kiedy to został częściowo rozformowany, a jego skład osobowy przekazano w części do dyspozycji $\mathrm{MBP}^{37}$. Po tej reorganizacji w OCW pozostało jedynie dwóch oficerów: szef cenzury wojskowej (cenzor wojenny Sztabu Głównego WP) - ppłk Roman Jarzębkiewicz oraz pomocnik szefa cenzury wojskowej (wcześniej odpowiedzialny za cenzurę „Rzeczpospolitej”) - kpt. Arkadiusz Proniński ${ }^{38}$.

35 IPN W, Zarząd II Sztabu Gen. WP, sygn. IPN BU 2602/33, Kpt. A. Proniński Sprawozdanie z działalności cenzury w Polsce [z załącznikami] dla szefa Wydziału Wywiadowczego Sztabu Głównego WP, [Łódź?] 8 VIII 1945, k. 118-125.

36 IPN W, Zarząd II Sztabu Gen. WP, sygn. IPN BU 2602/50, Ppłk Jarząbkiewicz, Pismo do Wydziału Cenzury Wojskowej MBP, 18 VII 1945 r., k. 46.

37 IPN W, Zarząd II Sztabu Gen. WP, sygn. BU 2602/54, Rozkaz nr 44/org, 3 III 1945 r., k. 59; B. Dolata, dz. cyt., s. 318.

38 IPN W, Zarząd II Sztabu Gen. WP, sygn. BU 2602/54, R. Jarzębkiewicz, Pismo do Wydziału Gospodarczego Sztabu Głównego WP, 7 VII 1945 r., k. 26; tamże, Wyciąg z Dziennika Personalnego Naczelnego Dowództwa WP, nr 160, 10 III 1945 r., k. 52; W. Jurgielewicz, Organizacja Ludowego Wojska Polskiego (22 VII 1944-9 V 1945), Warszawa 1968, s. 108; B. Dolata, dz. cyt., s. 318. 
Pozostali oficerowie cenzury zostali przeniesieni na etaty: por. Bolesław Kunach - cenzor „Polski Zbrojnej”, por. Aleksander Ostrowski - cenzor „Polpress" i Polskiego Radia, por. Euzebiusz Zwoliński - cenzor czasopism wojskowych „OSA” i „Pancerni”. Ponadto kpt. Jerzy Kuczewski miał objąć obowiązki cenzora 1. Armii WP, a por. Feliks Jurczyński obowiązki cenzora 2. Armii WP ${ }^{39}$. Faktycznie kpt. Kuczewski, zapewne z powodu swych obowiązków w krakowskim biurze cenzury, nie został cenzorem w 1. Armii, a na jego miejsce został przydzielony por. Bolesław Kunach ${ }^{40}$, kontrolę wychodzącej w Łodzi „Polski Zbrojnej” polecono natomiast kpt. Pronińskiemu ${ }^{41}$.

\section{Zadania i kadra cenzury wojskowej}

W lipcu 1945 roku Sztab Główny WP został przekształcony w Sztab Generalny WP, a wyniku tej reorganizacji OCW miał być ostatecznie zlikwidowany do 22 sierpnia $1945 \mathrm{roku}^{42}$. W miejsce dotychczasowej komórki utworzono Wydział IV Cenzury Wojskowej Oddziału Wywiadowczego Sztabu Generalnego WP, na czele którego stanął oddelegowany do WP oficer GRU - ppłk. Tadeusz („Fadiej”) Korojedow pełniący równocześnie funkcję pomocnika szefa wydziału w Oddziale Wywiadowczym Sztabu Generalnego WP43. Wedle etatu wprowadzonego rozkazem nr 0237/org., z 10 września 1945 roku, Wydział IV liczył trzy osoby: cenzora wojskowego, pomocnika cenzora oraz kancelistę ${ }^{44}$.

39 IPN W, Zarząd II Sztabu Gen. WP, sygn. BU 2602/49, Obsada Cenzury Wojskowej, k. 68.

40 Por. Kunach funkcję cenzora 1. Armii WP (kontrola redakcji gazety „Zwyciężymy”) pełnił do 20 IX 1945 r., (do czasu demobilizacji 1. Armii i organizacji DOW Śląsk) po czym został odwołany do dyspozycji Głównego Zarządu Informacji WP. IPN W, Zarząd II Sztabu Gen. WP, sygn. BU 2602/53, Por. B. Kunach, Meldunek do szefa Cenzury Wojskowej Sztabu Gen. WP, 8 X 1945 r., k. 32.

41 Z czasem kpt. Pronińskiemu powierzono kontrolę nad wszystkimi wojskowymi instytucjami wydawniczymi i tytułami prasowymi w Łodzi. Oprócz „Polski Zbrojnej”, były to: „Bellona” i „Żołnierz Polski”, a także prace wydawane przez Wojskowy Instytut Naukowo-Wydawniczy, Drukarnię Oddziału Propagandy Głównego Zarządu Polityczno-Wychowawczego Wojska Polskiego, Główną Księgarnię Wojskową. W XII 1945 r. kpt. Pronińskiego zastąpił kpt. Władysław Czarny. IPN W, Zarząd II Sztabu Gen. WP, sygn. BU 2602/53, Kpt. Proniński, Sprawozdanie 15 XI 1945 r., k. 7-8; tamże, Kpt. W. Czarny, Sprawozdanie, 30 XII 1945 r., k. 1-3.

42 IPN W, Zarząd II Sztabu Gen. WP, sygn. BU 2602/54, Płk. G. Bono, Pismo do Szefa Wojennej Cenzury WP, 11 IX 1945 r., k. 22.

43 IPN W, Zarząd II Sztabu Gen. WP, sygn. BU 2602/54, Ppłk T. Korojedow, Pismo do cenzora 1. Armii WP, 22 VIII 1945 r., k. 36; S. Cenckiewicz, dz. cyt., s. 71, 96.

44 IPN W, Zarząd II Sztabu Gen. WP, sygn. BU 2602/10241, Księga etatowa Zarządu II Sztabu Generalnego, k. 2, 21. 
29 października 1945 roku, w związku z demobilizacją, wyszło dodatkowo zarządzenie wydane przez szefa Sztabu Generalnego WP gen. Władysława Korczyca o powierzeniu cenzury wojskowej dowództwom okręgów wojskowych i dywizji ${ }^{45}$. Zadania oficerów pełniących obowiązki cenzorów regulowała wydana nieco wcześniej instrukcja, w myśl której wydawnictwa wojskowe, takie jak: gazety, książki, czasopisma, broszury, a także materiały przeznaczone dla radia, fotografie i filmy zrobione w oddziałach wojskowych oraz materiały wystawowe przed oddaniem ich do druku względnie przed ich upublicznieniem należało przesłać do dowództwa okręgu wojskowego na ręce oficera pełniącego obowiązki cenzora wojskowego w celu otrzymania zezwolenia na publikację ${ }^{46} .22$ października wyszedł także rozkaz o rozformowaniu oddziałów cenzury wojskowej przy okręgach wojskowych warszawskim, pomorskim i śląskim nr 40, 190 i 19147. Personel tych oddziałów przekazano do MBP.

Usytuowanie i podległość cenzorów wojskowych po 1945 roku nie jest do końca jasna i wymaga dalszych badań. Wiadomo natomiast, iż najpóźniej od 1948 roku cenzura wojskowa podlegała Głównemu Zarządowi Informacji WP (kontrwywiad wojskowy), podobnie jak utworzony wydział cenzury wojskowej w GUKPPiW ${ }^{48}$. 26 grudnia 1951 roku, zarządzeniem organizacyjnym nr 0355/org wydanym przez szefa Sztabu Generalnego WP, odpowiedzialny za cenzurę Wydział X Głównego Zarządu Informacji został zlikwidowany, a na jego bazie sformowano Wydział Cenzury Wojskowej Sztabu Generalnego WP49. Zakres obowiązków cenzorów wojskowych określono zarządzeniem Szefa Sztabu Generalnego, z 21 marca 1952 roku, o sposobie wykonywania przez cenzurę wojskową Sztabu Generalnego kontroli publikacji i widowisk wojskowych ${ }^{50}$, a 26 października 1953 roku WCW przekształcono w Oddział Cenzury Wojskowej (OCW). Wedle etatu 1/354, w składzie OCW znajdowały

45 A. Kochański, Polska 1944-1991. Informator historyczny, t. I, Warszawa 1996, s. 111, s. 18.

46 IPN W, Zarząd II Sztabu Gen. WP, sygn. BU 2602/93, Instrukcja dla oficerów pełniących czynności cenzorów wojskowych, 16 X 1945 r., k. 40.

47 K. Frontczak, Sity zbrojne Polski Ludowej. Przejście na stopę pokojową 1945-1947, Warszawa 1974, s. 145.

48 Z. Palski, Informacja Wojska Polskiego 1943-1957, Warszawa 2016, s. 16-18.

49 W. Hiller, Sztab Generalny WP 1951-1956, „Biuletyn Wojskowej Służby Archiwalnej” 1999, nr 22, s. 141, 156.

50 A. Kochański, Polska 1944-1991 ..., t. I, dz. cyt., s. 431. 
się następujące komórki: Kierownictwo, Wydział I Prewencji, Wydział II Instruktażu i Szkolenia oraz Kancelaria ${ }^{51}$.

Cenzorzy wojskowi odpowiadali za ochronę tajemnicy służbowej i państwowej, sprawowali nadzór nad zbiorami Centralnego Archiwum Wojskowego $^{52}$, a także od lat 40 . XX wieku czuwali nad przestrzeganiem instrukcji cenzorskich przez pracowników GUKPPiW. Pierwsze instrukcje dotyczące tajemnicy wojskowej przesłano cywilnym cenzorom już w 1945 roku. W instrukcji z października tego roku informowano podległych cenzorów między innymi o zakazie zamieszczania w prasie: informacji dotyczących mobilizacji Wojska Polskiego (o ile nie zostanie ogłoszona w specjalnych komunikatach); wiadomości dotyczących organizacji i wyposażenia jednostek WP; nazw, numerów oddziałów oraz nazwisk dowódców; podawania w prasie lokalizacji miejsc umocnionych, magazynów wojskowych i lotnisk; wiadomości o przeniesieniach oficerów; wiadomości dotyczących nowych typów broni w wojsku; czy informacji na temat braków w wyszkoleniu szeregowych i oficerów, a także „wszystkich wiadomości dotyczących ujemnych nastrojów oraz braków w stanie sanitarnym jednostek wojskowych”53. Instrukcja ta - „Wykaz wiadomości, których w prasie publikować nie wolno w czasie pokoju" - była kopią rozkazu wydanego cenzorom wojskowym przez szefa Wydziału Cenzury Wojskowej - ppłk. Tadeusza Korojedowa oraz szefa Oddziału Wywiadowczego Sztabu Generalnego WP - płk. Grigorija Domoradzkiego ${ }^{54}$.

W następnych latach instrukcje były rozszerzane i uzupełniane, między innymi o okólnik nr $111 \mathrm{w}$ sprawie zachowania tajemnic wojskowych z maja 1947 roku $^{55}$. Obok poleceń związanych z tajemnicą wojskową, cenzorzy mieli w swej pracy kierować się instrukcjami o „ochronie tajemnicy państwowej

51 W. Hiller, dz. cyt., s. 156.

52 W.K. Roman, Centralne Archiwum Wojskowe 1918-1998. Tradycje, historia, wspótczesność stużby archiwalnej Wojska Polskiego, Toruń 2009, s. 172, 176, 210, 218-219; A. Kochański, Polska 1944-1991 ..., t. I, dz. cyt., s. 418.

53 Archiwum Państwowe w Poznaniu (dalej: APP), Wojewódzki Urząd Kontroli Prasy Publikacji i Widowisk w Poznaniu (dalej: WUKPPiW Poznań), sygn. 7, Wykaz wiadomości, których w prasie publikować nie wolno w czasie pokoju, [Poznań 1945 r.], k. 12.

54 IPN W, Zarząd II Sztabu Gen. WP, sygn. BU 2602/52, Ppłk T. Korojedow, płk G. Domoradzki, Wykaz wiadomości, których w prasie publikować nie wolno w czasie pokoju, [X $1945 \mathrm{r}$.] k. 52; S. Cenckiewicz, dz. cyt., s. 66, 71.

55 APP, WUKPPiW Poznań, sygn. 7, Okólnik nr 111, Warszawa 2 V 1947 r., k. 75. 
na odcinku gospodarczym". Do tajnych zaliczono informacje dotyczące przemysłu zbrojeniowego, komunikacji (na przykład zdolności przepustowej linii i węzłów kolejowych), wiadomości o rezerwach towarowych (między innymi zboża i surowców), opisy ważnych wynalazków, kwoty inwestycji produkcyjnych oraz dane liczbowe o obrotach handlowych ${ }^{56}$. Liczba zapisów związanych z ochroną tajemnicy państwowej wzrastała wraz z przechodzeniem rządów komunistycznych w fazę stalinowską. Rozporządzenia w tym zakresie - obok kierownictwa GUKPPIW - wydawały władze państwowe, między innymi Komitet Ekonomiczny Rady Ministrów (KERM), kierownictwa poszczególnych resortów oraz dowództwo WP57. Liczba wydawanych zarządzeń, instrukcji, wykazów oraz uzupełnień i wyjaśnień do instrukcji przysyłanych do poszczególnych komórek terenowych cenzury była tak znaczna, że cenzorzy przestawali się z czasem orientować, które zapisy są aktualne i w jakim zakresie powinny być stosowane. W związku z tym dochodziło do licznych przeoczeń cenzorskich, a także do ingerencji „zbędnych”, a nawet „szkodliwych”. Podobne przypadki notowano między innymi w informacjach ze Śląska Opolskiego. W 1947 roku redakcja „Dziennika Zachodniego” opublikowała artykuł poświęcony zbiórce na sztandar 6. Drezdeńskiego Pułku Czołgów, który jesienią 1945 roku przybył do Opola. W ten sposób ujawniono miejsce stacjonowania jednostki, co odnotowano w specjalnym wykazie przeoczeń cenzorskich ${ }^{58}$.

Od 1 lutego 1947 roku cenzorom przybyły dodatkowe zadania w związku z przejęciem przez GUKPPiW kontroli nad wydawnictwami i widowiskami wojskowymi, do których dostęp miała także ludność cywilna ${ }^{59}$. Wśród kontrolowanych znalazły się między innymi tak zwane okręgówki, tj. gazety żołnierskie wydawane w poszczególnych okręgowych dowództwach wojskowych. Przejęcie nowych obowiązków wymagało od pracowników GUKPPiW

56 APP, WUKPPiW Poznań, sygn. 7, Okólnik nr 141 dyrektora GUKPPiW, Warszawa 19 IV 1948 r., k. 131.

57 Archiwum Państwowe w Zielonej Górze (dalej: APZG), Delegatura Głównego Urzędu Kontroli Prasy Publikacji i Widowisk w Zielonej Górze (dalej: DGUPPPiW Zielona Góra), sygn. 10, Uchwała Komitetu Ekonomicznego Rady Ministrów z dnia 12 VII 1949 r. w sprawie publikacji danych statystycznych, k. 52-54.

58 Archiwum Państwowe w Gdańsku, Wojewódzki Urząd Kontroli Prasy, Publikacji i Widowisk w Gdańsku, Pismo T. Zabłudowskiego w sprawie przeoczeń cenzorskich dotyczących tajemnicy wojskowej, Warszawa [1947 r.], k. 90.

59 B. Gogol, dz. cyt., s. 236. 
zwiększonej czujności i szerokiej znajomości instrukcji oraz zarządzeń związanych z ochroną tajemnicy państwowej. Nie było to jednak łatwe wobec ich nadmiaru. Niewątpliwie w związku z tymi problemami 25 czerwca 1948 roku dyrektor GUKPPiW wydał nowe zarządzenie o zachowaniu tajemnicy wojskowej w prasie, publikacjach i widowiskach. Celem tego zarządzenia, jak informowano pracowników cenzury, było niedopuszczenie do powtarzających się przeoczeń cenzorskich i niepotrzebnych oraz szkodliwych ingerencji. W instrukcji zawarto dane, które wolno było rozpowszechniać, a także informacje, których ujawnienie było niedozwolone. W związku z tym, że podane winstrukcjiinformacjemiały charakter przykładowy,nakazywanow wątpliwych wypadkach zwracać się po wskazówki do władz wojskowych: w Warszawie do Wydziału Prasowego MON, a w terenie - do odpowiedzialnych za sprawy polityczno-wychowawcze zastępców dowódców okręgów wojskowych ${ }^{60}$.

Pod koniec lat 40. nastąpiło dalsze porządkowanie spraw związanych $\mathrm{z}$ ochroną tajemnicy państwowej oraz dotyczących tej kwestii specjalnych instrukcji. Wydawane zarządzenia podzielono na trzy rodzaje, z uwzględnieniem charakteru chronionych informacji. W ten sposób powstawały osobne instrukcje dotyczące: tajemnicy gospodarczej, tajemnicy wojskowej i tajemnicy wojskowo-komunikacyjnej61. Jednocześnie władze państwowe wydały dekret o ochronie tajemnicy państwowej i służbowej, w którym przewidywano kary więzienia do 10 lat, między innymi dla osób ujawniających lub ogłaszających „wiadomości, dokumenty lub inne przedmioty stanowiące tajemnicę państwową"62. Dekret wszedł w życie 12 listopada 1949 roku i obowiązywał przez 20 lat, stając się podstawą prawną dla kolejnych przepisów regulujących sprawy tajemnicy państwowej63.

60 APP, WUKPPiW Poznań, sygn. 7, Zarządzenie z dnia 25 VI 1948 r., nr V.4 s/5, k. 144-147.

61 B. Gogol, dz. cyt., s. 235.

62 Dz.U. 1949, nr 55, poz. 437.

63 Dekret z 1949 r. uchylił art. VI ustawy z 19 kwietnia 1969 r. - Przepisy wprowadzające Kodeks karny. G. Goryński, Prawne podstawy ochrony informacji niejawnych w Polsce, „Colloquium Wydziału Nauk Humanistycznych i Społecznych” 2013, nr 1, s. 105. 


\section{Wydział Wojskowy GUKPPiW}

Kolejnym ważnym posunięciem władz było powierzenie kontroli prewencyjnej w zakresie ochrony tajemnicy państwowej oficerom cenzury wojskowej64. 13 września 1949 roku, rozkazem Ministra Obrony Narodowej, sformowano Wydział Wojskowy GUKPPiW, który zastąpił wcześniej istniejący Referat Wojskowo-Ekonomiczny GUKPPiW ${ }^{65}$. W pierwszych latach istnienia komórką wojskową kierował w GUKPPiW mjr/płk Tadeusz Polanowski, który po 1956 roku został przeniesiony do Sztabu Generalnego WP na stanowisko szefa OCW66. W 1949 roku w Wydziale Wojskowym GUKPPiW służyli: szef - mjr Tadeusz Polanowski, starszy cenzor - por. Ignacy Musiał, sekretarz Henryka Iwanik oraz maszynistka - Jadwiga Brodowska ${ }^{67}$.

W czasach PRL nazwa komórki wojskowej ulokowanej w strukturze GUKPPiW wielokrotnie ulegała zmianie; w latach 50. był to kolejno Wydział Wojskowy i Wydział Specjalny ${ }^{68}$. Po odwilży 1956 roku ponownie przyjęto nazwę Wydział Wojskowy, który następnie przekształcono w Samodzielny Wydział Wojskowy ${ }^{69}$. W 1983 roku komórkę tę nazwano Samodzielnym Wydziałem Spraw Obronnych ${ }^{70}$, a pod koniec istnienia GUKPiW w 1987

\footnotetext{
64 A. Kochański, Polska 1944-1991 ..., t. I, dz. cyt., s. 111.
}

65 W dostępnej literaturze istnieje rozbieżność dotycząca daty utworzenia Wydziału Wojskowego; podawany jest 1 lub 13 IX 1949 r. Wymieniane są także różne osoby odpowiedzialne za to zarządzenie: Minister Obrony Narodowej lub I Wiceminister Obrony Narodowej. W. Tkaczew, Organa informacji Wojska Polskiego 1943-1956. Kontrwywiad wojskowy, Warszawa 2007, s. 52; A. Kochański, Polska 1944-1991 ..., t. I, dz. cyt., s. 292-293.

66 Płk Tadeusz Polanowski kierował Oddziałem Cenzury Wojskowej Sztabu Gen. WP do lat 60. XX w., kiedy to został zwolniony na fali czystek antysemickich. Polanowskiemu zarzucono posiadanie rodziny w Belgii, niedostateczne działania w celu zabezpieczenia tajemnicy wojskowej w pracy Wojskowej] A[kademii] T[echnicznej] i Czołówki Filmowej WP oraz fakt, że „przyjaźnił się ze zdrajcą [Józefem] Światło”. Nowym szefem OCW został płk dypl. Stanisław Książkiewicz, wcześniej pełniący służbę w Zarządzie II GZI WP. T. Pióro, Czystki w Wojsku Polskim 1967-1968, „Biuletyn Żydowskiego Instytutu Historycznego” 1997, nr 2, s. 61-62; W. Tkaczew, dz. cyt., s. 26; Archiwum Akt Nowych (dalej: AAN), Główny Urząd Kontroli Prasy Publikacji i Widowisk (dalej: GUKPPiW), sygn. 1635, Płk S. Książkiewicz, Zapisy cenzorskie, [Warszawa III 1967 r.], k. 79.

67 W. Tkaczew, dz. cyt., s. 52.

68 Wydział Specjalny (w korespondencji używano skrótu WS) został powołany rozporządzeniem Prezesa RM z 6 XI 1952 r. „,elem zwiększenia stopnia ochrony tajemnicy państwowej drogą stałego nadzoru". Cyt. za: B. Gogol, dz. cyt., s. 236.

69 APP, WUKPPiW Poznań, sygn. 3, k. 19; AAN, GUKPPiW, sygn. 1438, k. 98.

70 „Monitor Polski” 1983, nr 16, poz. 89. 
roku przemianowano ją na Biuro Spraw Obronnych ${ }^{71}$. Cenzurą wojskową w GUKPPiW kierowali po 1956 roku naczelnicy (prawdopodobnie nie jest to pełna lista nazwisk): płk Anatol Leszczyński (naczelnik Wydziału Wojskowego w latach 1956-1967) ${ }^{72}$, płk Zdzisław Pancer (wcześniej oficer GZI, na stanowisku naczelnika Wydziału Wojskowego zatrudniony najdłużej - od 1967 do 1984 roku) ${ }^{73}$ oraz płk Stanisław Wojtala (1984-1990?) $)^{74}$. Do pracowników Wydziału Wojskowego należeli doświadczeni cenzorzy, absolwenci szkół sowieckich. Przykładem może być ppłk Stanisław Klaro (Klarow) - oficer sowiecki, adept specjalnej szkoły oficerskiej w Kujbyszewie i funkcjonariusz organów bezpieczeństwa publicznego ${ }^{75}$.

Do zadań pracowników Wydziału Wojskowego, już w latach 50. XX wie$\mathrm{ku}$, należało: opracowywanie instrukcji cenzorskich, przeglądów ingerencji cenzorskich, a także nadzór i szkolenie kadr GUKPPiW w dziedzinie ochrony tajemnicy państwowej ${ }^{76}$. Począwszy od lat 60 . XX wieku cenzorzy wojskowi odpowiadali natomiast za redakcję jednego z najważniejszych dokumentów niezbędnych w pracy cenzorów GUKPPiW, jaką była „Instrukcja o zachowaniu tajemnicy państwowej i służbowej w publikacjach jawnych" wprowadzona w życie zarządzeniem wewnętrznym nr 4 prezesa GUKPPiW z 10 kwietnia $1964 \mathrm{roku}^{77}$.

71 AAN, GUKPPiW, sygn. 1855, k. 36; tamże, sygn. 2109, k. 4; M.P. 1987, nr 18, poz. 151.

72 APZG, DGUKPPiW Zielona Góra, sygn. 9, k. 23; IPN W, sygn. BU 2174/6404, J. Siemek, Opinia o Z. Pancerze, Warszawa 9 VIII 1970 r., k. 19.

73 IPN W, sygn. BU 2174/6404, S. Kosicki, Opinia o płk. Zdzisławie Pancerze, Warszawa 7 VI 1975, k. 18; W oficjalnym nekrologu płk. Zdzisława Pancera nie ujawniono informacji o jego pracy w GUKPPiW, napisano natomiast: „długoletni pracownik Sztabu Generalnego, aktywny członek PPR i PZPR”. Kronika, „Wojskowy Przegląd Historyczny” 1986, nr 1, s. 268.

74 AAN, GUKPPiW, sygn. 1950, k. 2.

75 IPN W, sygn. BU 2174/1009, S. Klaro, Życiorys, Warszawa 5 VI 1958 r., k. 19. Nekrolog [Stanisława Klaro], „Stolica” 1965 z 17 X, nr 42, s. 10.

76 Zgodnie z zarządzeniem z 14 IX 1950 r. naczelnicy WUKPPiW zobowiązani byli nadsyłać do Wydziału Wojskowego UKPPiW ,imienno-ilościowe sprawozdania z ingerencji i przeoczeń po linii ochrony tajemnicy państwowej”. APP, WUKPPiW Poznań, sygn. 7, W. Chabowski, Pismo okólne, Warszawa 14 IX 1950 r., k. 285.

77 AAN, GUKPPiW, sygn. 1635, Ppłk A. Leszczyński, Pismo do Gabinetu Prezesa GUKPPiW, Warszawa 3 III 1967 r., k. 32. Szerzej o instrukcjach cenzorskich w: M. Patelski, „Czujni strażnicy demokracji” ludowej. Urząd cenzury w województwie opolskim 1950-1990, Opole 2019, s. 153-163. 
W „Regulaminie organizacyjnym GUKPPiW” z 1967 roku do zadań Samodzielnego Wydziału Wojskowego zaliczono prowadzenie oraz koordynację kwestii zabezpieczenia tajemnicy służbowej i państwowej w urzędzie, a zakres jego działań określały odrębne przepisy, których nie udało się odnaleźć. Wydział Wojskowy prowadził ponadto w GUKPPiW kancelarię tajną ${ }^{78}$. Szczególne obowiązki ciążyły na naczelniku Wydziału Wojskowego. W latach 70. XX wieku pełniący tę funkcje płk Pancer miał za zadanie przygotowanie GUKPPiW do działań w systemie obronności kraju, w tym opracowywanie ćwiczeń dowódczo-sztabowych. Naczelnik Wydziału koordynował ponadto współpracę Głównego Urzędu z Oddziałem V Ochrony Tajemnicy Sztabu Gen. WP, był konsultantem dla wszystkich komórek GUKPPiW w dziedzinie stosowania instrukcji o zachowaniu tajemnicy wojskowej, odpowiadał za przygotowywanie cenzorskich dyrektyw z zakresu ochrony tajemnicy państwowej i służbowej, a także kierował instruktażem w tym zakresie ${ }^{79}$.

Obok spraw gospodarczych cenzorzy wojskowi kładli duży nacisk na ścisłe przestrzeganie tajemnicy wojskowej w publikacjach jawnych. Chroniono zarówno takie drażliwe informacje, jak dyslokacja oddziałów wojskowych, jak i specyficznie pojęte „dobre imię” sił zbrojnych i służących tam żołnierzy. Poznański cenzor Edward Pawlak wspominał: „Szczególny parasol ochronny roztoczono nad naszą armią. Była ona świętą krową, od której trzeba było odganiać nie tylko bąki, ale także drobne muszki. Nic nie mogło skalać jej dobrego imienia. Żołnierze musieli być mężni, piękni i wspaniali na każdą okazję"80. Działania te często służyły eliminowaniu informacji dotyczących drobnych wykroczeń jak i przestępstw dokonywanych przez żołnierzy i oficerów WP, a także tekstów, które mogły ośmieszać wojsko. Usuwanie z prasy tego typu informacji uzasadniano zwykle ich „negatywną wymową dla interesów obronności kraju"81. W sytuacjach szczególnej wagi decyzje

78 Archiwum Państwowe w Rzeszowie, Wojewódzki Urząd Kontroli Prasy Publikacji i Widowisk w Rzeszowie, sygn. 85, Regulamin organizacyjny GUKPPiW, Warszawa I 1967 r., k. 35.

79 IPN W, sygn. BU 2174/6404, S. Kosicki, Opinia o płk. Zdzisławie Pancerze, Warszawa 7 VI 1975, k. 18.

80 E. Pawlak, Moje matżeństwo z cenzura, cz. 3, „Wprost” 1990, nr 8, s. 23.

81 W przygotowanych dla najwyższych władz wojskowych oraz dla kierownictwa GUKPPiW „Informacjach SWW GUKPPiW o ingerencjach w materiałach o tematyce militarnej” z 1974 r. napisano między innymi o usuwaniu fragmentów tekstów prasowych dotyczących: wypadków 
o ingerencjach konsultowano z Oddziałem Prasy i Informacji Głównego Zarządu Politycznego WP ${ }^{82}$.

Istniejąca w okresie PRL cenzura wojskowa do dziś pozostaje jedną z najmniej znanych i opisanych służb kontrolujących media i przepływ informacji w Polsce pod rządami komunistów. Jak wynika z odnalezionych materiałów źródłowych, wojskowe służby cenzorskie, zorganizowane wedle wzorców sowieckich i pod nadzorem oficerów z GRU, miały istotny wpływ na działanie cenzury w Polsce. Na przełomie 1944 i 1945 roku, gdy ważyły się losy struktur cenzury cywilnej, służby wojskowe próbowały zmonopolizować kontrolę prasy i radia, a wyrazem tego było powołanie Oddziału Cenzury Wojskowej. Ostatecznie cenzura cywilna - CBKP, a następni GUKPPiW, została zorganizowana przez resort bezpieczeństwa i przekazana pod bezpośrednie kierownictwo Rady Ministrów. Dowództwo wojskowe nie poprzestało jednak zabiegać o wpływ na tę instytucję, do struktur Głównego Urzędu wprowadzono komórkę wojskową - Wydział Wojskowy GUKPPiW związaną z wojskowymi służbami informacyjnymi. Pracownicy Wydziału Wojskowego odpowiedzialni za ochronę tajemnicy wojskowej, przez cały okres PRL zabezpieczali szeroko rozumiane interesy wojskowe, a ich rola i skutki działań niewątpliwie wymagają dalszych, szczegółowych badań.

samochodowych, niszczenia lasów i przejazdów kolejowych przez wojskowe pojazdy gąsienicowe, a także o ingerencjach w „Słowniku gwary studenckiej”, z którego usunięto obszerne hasło „Studium wojskowe”. IPN W, Szefostwo WSW w Warszawie, sygn. BU 2386/19710, „Informacje SWW GUKPPiW o ingerencjach w materiałach o tematyce militarnej” (1 I-31 XII 1974), Warszawa 1975, k. 98-101.

82 Podobny los spotkał artykuł Bronisława Bednarza pt. „Marszałkowie z fotografii”, poświęcony życiorysom dowódców sowieckich, zgłoszony do druku w tygodniku „Polityka”. Z biografii niektórych marszałków usunięto między innymi informację o ich służbie w armii carskiej. M. Rakowski, Dzienniki polityczne, t. 6, Warszawa 2002, s. 28-30. 


\section{Bibliografia}

Błagowieszczański I., Dzieje 1 Armii Polskiej w ZSRR. Maj-lipiec 1944 r., Warszawa 1972.

Cenckiewicz S., Długie ramię Moskwy. Wywiad wojskowy Polski Ludowej 19431991, Warszawa 2009.

Ciećwierz M., Polityka prasowa 1944-1948, Warszawa 1989.

Dolata B., Krótki zarys rozwoju władz naczelnych i instytucji Ludowego Wojska Polskiego w latach 1944-1945, [w:] Z zagadnień rozwoju Ludowego Wojska Polskiego, pod red. J. Margulesa, Warszawa 1964, s. 38-73.

Dolata B., Zarys organizacji i działalności Sztabu Głównego Wojska Polskiego w latach 1944-1945, „Wojskowy Przegląd Historyczny” 1968, nr 3, s. 289-343.

Drzewiecka S., 1 Samodzielny Batalion Kobiecy im. Emilii Plater, „Wojskowy Przegląd Historyczny" 1958, nr 3, s. 177-207.

Drzewiecka S., Szłyśmy znad Oki, Warszawa 1985.

Frontczak K., Siły zbrojne Polski Ludowej. Przejście na stopę pokojową 1945-1947, Warszawa 1974.

Główny Urząd Kontroli Prasy 1945-1949, oprac. D. Nałęcz, Warszawa 1994.

Goryński G., Prawne podstawy ochrony informacji niejawnych w Polsce, „Colloquium Wydziału Nauk Humanistycznych i Społecznych" 2013, nr 1, s. 99-127.

Hiller W., Sztab Generalny WP 1951-1956, „Biuletyn Wojskowej Służby Archiwalnej” 1999, nr 22, s. 140-157.

Jurgielewicz W., Organizacja Ludowego Wojska Polskiego (22 VII 1944-9 V 1945), Warszawa 1968.

Kochanowski J., Lubelskie czarne gabinety. Sprawozdania cenzury wojennej z 1944 roku. „Polska 1944/45-1989. Studia i Materiały” 1999, t. IV, s. 325-337.

Kochański A., Polska 1944-1991. Informator historyczny, t. I, Warszawa 1996.

Majchrzak G., „Wojenna” cenzura, „Biuletyn Instytutu Pamięci Narodowej” 2004, nr 2, s. 50-53.

Nekrolog [Stanisława Klaro], „Stolica” 1965 z 17 X, nr 42, s. 10.

Nogaj A., Powstanie i organizacja Oddziału Wywiadowczego Sztabu Głównego Wojska Polskiego w latach 1944-1945, [w:] Studia nad wywiadem i kontrwywiadem Polski w XX wieku, t. 1, pod red. W. Skóry i P. Skubisza, Szczecin 2016, s. 479-578. Oczkowski M., Zmiany w organizacji i zakresie działania władz administracji ogólnej, „Gazeta Administracyjna” 1945, nr 1-3, s. 22-35. 
Organizacja i działania bojowe Ludowego Wojska Polskiego w latach 1943-1945, t. 1, oprac. L. Ponahajba, Warszawa 1958.

Pakier P., Prasa frontowa Ludowego Wojska Polskiego w latach 1943-1945, „Rocznik Historii Czasopiśmiennictwa Polskiego" 1967, z. 1, s. 126-154.

Palski Z., Informacja Wojska Polskiego 1943-1957, Warszawa 2016.

Patelski M., "Czujni strażnicy demokracji” ludowej. Urząd cenzury w województwie opolskim 1950-1990, Opole 2019.

Pawlak E., Moje małżeństwo z cenzurą, cz. 3, „Wprost” 1990, nr 8, s. 22-24.

Pióro T., Czystki w Wojsku Polskim 1967-1968, „Biuletyn Żydowskiego Instytutu Historycznego" 1997, nr 2, s. 59-76.

Rakowski M., Dzienniki polityczne, t. 6, Warszawa 2002.

Roman W. K., Centralne Archiwum Wojskowe 1918-1998. Tradycje, historia, wspótczesność służby archiwalnej Wojska Polskiego, Toruń 2009.

Romek Z., Cenzura a nauka historyczna w Polsce 1944-1970, Warszawa 2010.

Sowiński P., Kontrola pierwszomajowa, „Karta” 1998, nr 25, s. 4-23.

Stępniowski T., Z dziejów 2 Armii Wojska Polskiego. Zarys formowania i organizacji, Warszawa 1962.

Tkaczew W., Organa informacji Wojska Polskiego 1943-1956. Kontrwywiad wojskowy, Warszawa 2007.

Wojsko Polskie w II wojnie światowej, pod red. E. Kospath-Pawłowskiego, Warszawa 1994. 